Vol. 17 (2008): 53-62.

\title{
The impact of agriculture on autumn staging Eurasian Cranes (Grus grus) in Estonia
}

\author{
Aivar Leito \\ Institute of Agriculture and Environmental Sciences, Estonian University of Life Sciences, \\ 64 Kreutzwaldi St., Tartu 51014, Estonia, e-mail: aivar.leito@emu.ee \\ Jaak Truu \\ Faculty of Biology and Geography, University of Tartu, 23 Riia St., Tartu 51010, Estonia \\ Maris Õunsaar, Kalev Sepp, Are Kaasik, Ivar Ojaste \\ Institute of Agriculture and Environmental Sciences, Estonian University of Life Sciences, \\ 64 Kreutzwaldi St., Tartu 51014, Estonia \\ Eve Mägi \\ Matsalu National Park, State Nature Conservation Centre, Hiiu-Lääne Region, Penijõe, \\ Lihula 90305, Läänemaa, Estonia
}

This paper explores the relation between the local numbers and distribution of autumn staging Eurasian Cranes (Grus grus Linn.) and agricultural land use during recent decades in Estonia. The analysis is based on the long-term monitoring data of staging cranes and the statistical data of land use in Estonia. We found that great changes in cropping area, as well as in crane numbers have taken place in Estonia since the 1960s. We also found a significant positive correlation between crane numbers and the cropping area of summer wheat, winter wheat, winter rye and all cereals together, and a negative correlation with the area of potatoes. Generally, arable land, particularly that used for growing cereals, has a great influence on the local numbers and distribution of staging cranes. Based on our findings, we predict that changes in the local numbers and distribution of Eurasian Cranes staging during their migration in Estonia and elsewhere will depend on changes in agricultural land use in staging areas, rather than on the size of the breeding population. As about 10 percent of the European Eurasian Crane population stop over in Estonia during the autumn migration, the country has an important role to play in the protection of the species.

Key-words: Eurasian Crane, staging cranes, crane protection, land use change, agricultural policy, Estonia 


\section{AGRICULTURAL AND FOOD SCIENCE}

\section{Leito et al. The impact of agriculture on migrating cranes}

\section{Introduction}

The Eurasian Crane is distributed in Eurasia from latitude $69^{\circ} \mathrm{N}$ to latitude $40^{\circ} \mathrm{N}$ and from longitude $6^{\circ} \mathrm{E}$ to longitude $165^{\circ} \mathrm{E}$ (Cramp and Simmons 1980, Prange 1989, Meine and Archibald 1996). Its recent European breeding population is about 110,000 pairs (Prange 2003, BirdLife International 2004). Breeding populations have increased across most of Europe. In Estonia the breeding population of the Eurasian Crane has increased from about 300 pairs in 1970 up to 6800 pairs in 2006 (Leito et al. 2003, 2006, Leito pers. comm.). Eurasian Cranes are omnivores, mostly feeding carnivorously during breeding and herbivorously during the migration and wintering periods (Cramp and Simmons 1980, Prange 1989, Díaz et al. 1996, Avilés et al. 2002). The composition of their diet depends on the season and local foraging opportunities. In Estonia, the main feeding habitats for cranes in the autumn are fields of different cereals and mowed grasslands (Leito et al. 2006).

During the period from the 1960 s to the 2000s, the numbers of cranes that stopped over during the autumn migration has increased to a greater or lesser extent in all of the most important staging areas in Europe. The growth and relative importance of staging sites have, however, varied greatly from one year to another (Lundin 2005). In Estonia, the total number of staging cranes rose continuously during the 1960s and 1970s and has stabilised in the period from the $1980 \mathrm{~s}$ to $2000 \mathrm{~s}$. At the beginning of the $1960 \mathrm{~s}$, up to 5000 cranes, and in the $1980 \mathrm{~s}$ and 1990s, between 20,000 and 30,000 cranes were counted (Leito et al. 2006). All together, the Eurasian Crane population migrating on the WestEuropean migratory route has increased from about 40,000 to 150,000 birds, and the number of cranes migrating on the Baltic-Hungarian route has increased from about 30,000 to 90,000 during the past 30 years (Prange 1999, 2003, Lundin 2005). Cranes breeding in Estonia use all the Eurasian Crane migratory routes in Europe, but are most numerous on the West-European and Baltic-Hungarian migratory routes (Leito et al. 2006).

Although Eurasian Crane numbers have increased substantially throughout Europe during re- cent decades, its breeding range has not yet reached the former distribution range, and its population has not yet recovered to the level that preceded its decline. In the list of Species of European Conservation Concern (SPECs) the Eurasian Crane is listed in SPEC category 2 (a species whose global populations are concentrated in Europe and which has an Unfavourable Conservation Status in Europe) (BirdLife International 2004).

Another aspect of the concentration of cranes on arable land during migration and wintering is that, if present in large numbers, cranes may cause serious damage to crops. There are two possible ways to solve this problem - to compensate the damages and/or create artificial feeding fields for cranes, and both schemes are in use (Koskinen et al. 2003, Lundin 2005, Nowald 2005, Petit and Couzi 2005). In Estonia, on the basis of the Fauna Protection and Use Act, the Regulation on Procedure and Methodology for Assessment of Damage Caused by Protected Animals or Birds on Migration was implemented in 1994. The guiding principle of the Regulation is to compensate the actual crop damage caused by animals and birds on migration, including that of staging cranes.

Many different policy measures, including agri-environment schemes, have been implemented across Europe, mostly addressing water, biodiversity, and landscape protection. In the late 1990s about $20 \%$ of farmland in the European Union (EU) was covered by national agri-environmental programmes (OECD 2003, Bayliss et al. 2005, Carey et al. 2005, Herzog 2005). Evaluation of their effects on biodiversity is, however, difficult from a methodological standpoint, and the existing studies are often controversial. More research on agri-environment schemes, other policy measures, and farming is needed in order to assess and improve their actual influence on different species, including cranes (Alonso et al. 1987, 1994, Prange 1999, Alonso et al. 2003, Bayliss et al. 2005, Lundin 2005).

We conducted a thorough survey of the numbers and distribution of Eurasian Cranes staging during the autumn migration in Estonia in relation to changes in agricultural policy and land use, particularly changes in cropping areas. The main goal of this study was to analyse the long-term dynamics of 
Vol. 17 (2008): 53-62.

agricultural land use and numbers of autumn staging cranes in Estonia in order to assess whether and how agricultural practice affects the local numbers and distribution of staging cranes and to ascertain the importance of agricultural policy and land use for migrating birds.

\section{Material and methods}

\section{Crane censuses}

The autumn staging of the Eurasian Crane has been monitored in the Matsalu area since 1961, on Hiiumaa Island since 1982 and throughout Estonia since 1983. In Matsalu and Hiiumaa, censuses have been carried out almost every year. Total crane counts were conducted in the years 1983, 1994, 1999, 2000 and 2003. In these years the total counts were carried out in all the sites in Estonia where cranes stay during the autumn. Censuses were performed using the standard method developed in Estonia (Keskpaik et al. 1986). The census period lasts two weeks, from the middle to the end of September, with a central counting day on the weekend in the second half of September. According to this method, cranes are counted at the roosting sites during the flight from feeding site to roosting site in the evening. If the evening census is not successful due to bad weather (fog or heavy rain), the census is repeated the next morning.

\section{Agricultural land use}

The data on area and yields of winter rye, winter wheat, summer wheat, barley, oats, potato and hay, and for the total area of cereals and for all crops together in Hiiumaa and Läänemaa Counties and for the whole of Estonia from 1965-2005 were collected from the archive of the Estonian Farmers' Union and from the Statistical Office of Estonia (2006). Data on crop yields were not used for further analyses because the data was not complete for every year.
The area characteristics of cultivated crops that we used should be even better than crop yield data, because cranes feeding on fields, apart from eating germinated grains or the leaves of sprouted cereals, also eat invertebrates, amphibians and small mammals living in the fields. In this way, the food source for cranes on arable land contains both the crops cultivated there and the accompanying edible small animals, and our results reflect the effect of the available food complex on crane distribution and numbers.

In Hiiumaa County (area $1019 \mathrm{~km}^{2}$ ), the cultivated areas of crops coincide with the feeding area of cranes, since the birds feed on all fields throughout the island. The crane staging population of the Matsalu region is spread over about 2000 $\mathrm{km}^{2}$, which makes up about $84 \%$ of the territory of Läänemaa County (area $2394 \mathrm{~km}^{2}$ ). Consequently the agricultural indicators for the whole of Läänemaa County are representative for the Matsalu crane population. The total land area of Estonia without Lake Peipsi and Lake Võrtsjärv is 43,428 $\mathrm{km}^{2}$ (Maansoo 2001), and agricultural land currently makes up about $20.5 \%\left(8890 \mathrm{~km}^{2}\right)$ of this (Statistical Office of Estonia 2002).

\section{Data analysis}

The coefficient of variation $(\mathrm{CV})$ was calculated in order to demonstrate the temporal variation of crane numbers and cropping area. Ordination of cropping areas of different crops according to year in Hiiumaa, Matsalu and in Estonia as a whole were analysed using principal component analysis (PCA). The Spearman rank order correlation coefficient $\left(r_{s}\right)$ was used to examine the relationship between crane numbers and cropping area in the same year in the Hiiumaa and Matsalu areas over the period 1965-2004. The Mann-Kendall test $(M K)$ was used to find the presence of monotonic trends in time series. Locally weighted regression (LOWESS) was used to illustrate trends in the time series data of crane numbers. Correlations and LOWESS were calculated using the computer programme Statistica. 


\section{AGRICULTURAL AND FOOD SCIENCE}

Leito et al. The impact of agriculture on migrating cranes

\section{Results}

\section{Crane numbers and distribution}

During the period 1982-2005, the number of autumn staging cranes on Hiiumaa has varied between 960 in 1998 and 4230 in 1993 ( $C V=1.69, n=21$ years) (Fig. 1). Four different periods in crane numbers can be distinguished on the basis of figure 1: (1) relatively stable numbers at a low level in the 1980s; (2) population growth with a peak in numbers at the beginning of the 1990s; (3) a rapid decrease in numbers until 1998, and (4) relatively stable numbers from 1999-2005, remaining at the same level as in the 1980s.

During the period 1961-2005 the number of staging cranes in Matsalu has varied between 700 in 1996 and 21,500 in $1994(C V=2.41, n=30$ years) (Fig. 2). Three main periods can be distinguished for Matsalu on the basis of figure 2: (1) a substantial population growth from 1965-1983, (2) a period with fluctuating numbers at a level of about 10,000 cranes, and (3) a new growth period during the last decade since 1995. There is a significant positive trend in staging crane abundance over the whole study period 1961-2005 $(M K=2.66, p<$ $0.01, n=30$ years).

Based on total counts during the period 1983-2003, the number of autumn staging Eurasian Cranes in Estonia has varied between 18,000 in 1997 and 30,000 in 1994 ( $C V=0.51, n=5$ years). The total number of cranes has fluctuated without any visible trend (Fig. 3). A total of 51 crane staging sites in 8 concentration areas were established in the 1980 s, and 61 staging sites in 10 concentration areas in the 1990s. The main concentration areas of staging cranes are located in the western, southeastern and northern part of Estonia (Fig. 4). All of the most important staging sites are situated in areas of large fields close to wetland. The most important gathering area has been Western Estonia, including the islands of Hiiumaa and Saaremaa, where, in different years between 1983 and 2003, 72\% and $87 \%(n=5)$ of all cranes were counted. The relative share of all staging cranes in Matsalu has been $48-71 \%(n=5)$ during the period $1983-2003$. This

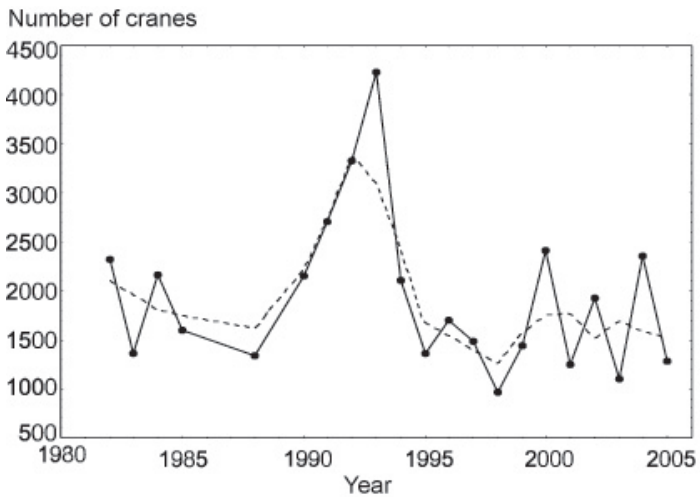

Fig. 1. Temporal dynamics of crane numbers on the island of Hiiumaa. The solid line represents the actual counted crane number and the dashed line reflects robust locally weighted regressions (LOWESS) over time.

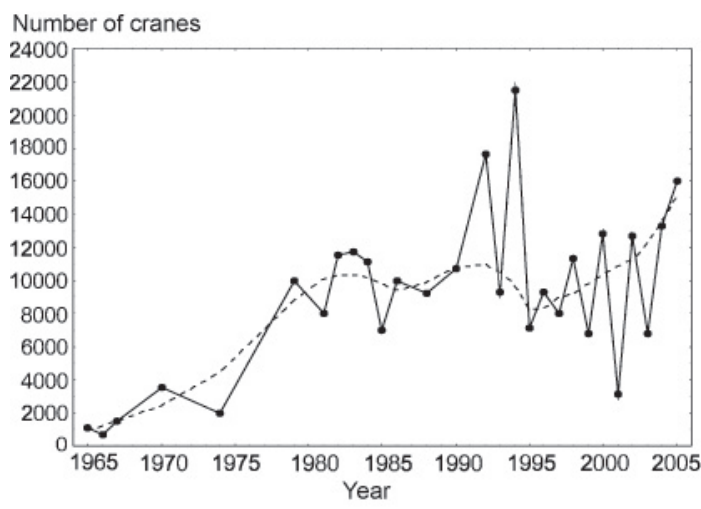

Fig. 2. Temporal dynamics of crane numbers in Matsalu. The solid line represents the actual counted crane number and the dashed line reflects robust locally weighted regressions (LOWESS) over time.

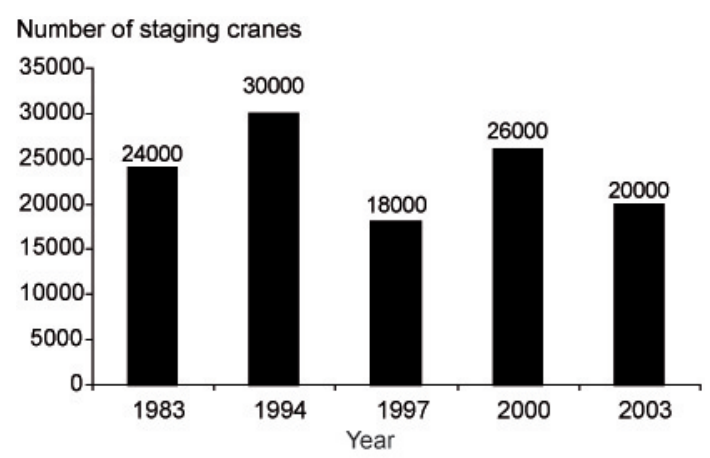

Fig. 3. Total numbers of autumn staging Eurasian Cranes counted in Estonia, 1983-2003 (After Leito et al. 2006). 
Vol. 17 (2008): 53-62.

area is characterized by a large shallow-water sea bay and large fields in the surroundings. There is a significant positive correlation between the number of cranes staging in Hiiumaa and in Matsalu $\left(r_{s}=\right.$ 0.47, $p<0.05, n=21)$ and between Matsalu and Estonia as a whole $\left(r_{s}=0.90, p<0.05, n=5\right)$.

\section{Relationships between crane numbers and cropping area}

During the period 1965-2004, the total area of cropland in Estonia has varied from 259,248 ha in 2002 to 444,223 ha in $1980(C V=0.55, n=40)$
(Fig. 5a). The dynamics of the total area of cropland in Läänemaa County, Hiiumaa County and in the whole of Estonia has been similar (Fig. 5a, b). Five main periods in the total area of field crops can be distinguished for Estonia on the basis of figure 5: (1) the growth in total area in the period 1965-1976, (2) a relatively stable total area in the period 1977-1992, (3) a rapid decrease in the period 1993-1996, (4) a new increase and stabilisation on a lower level at the end of the 1990s, and (5) stabilisation in total area of field crops at a new level close to that of the 1960s. There is no significant linear trend in total area of field crops in Hiiumaa County $(M K=0.32$, $p>0.05, n=49)$, Läänemaa County $(M K=1.14$, $p>0.05, n=40)$ and in Estonia as a whole $(M K=$

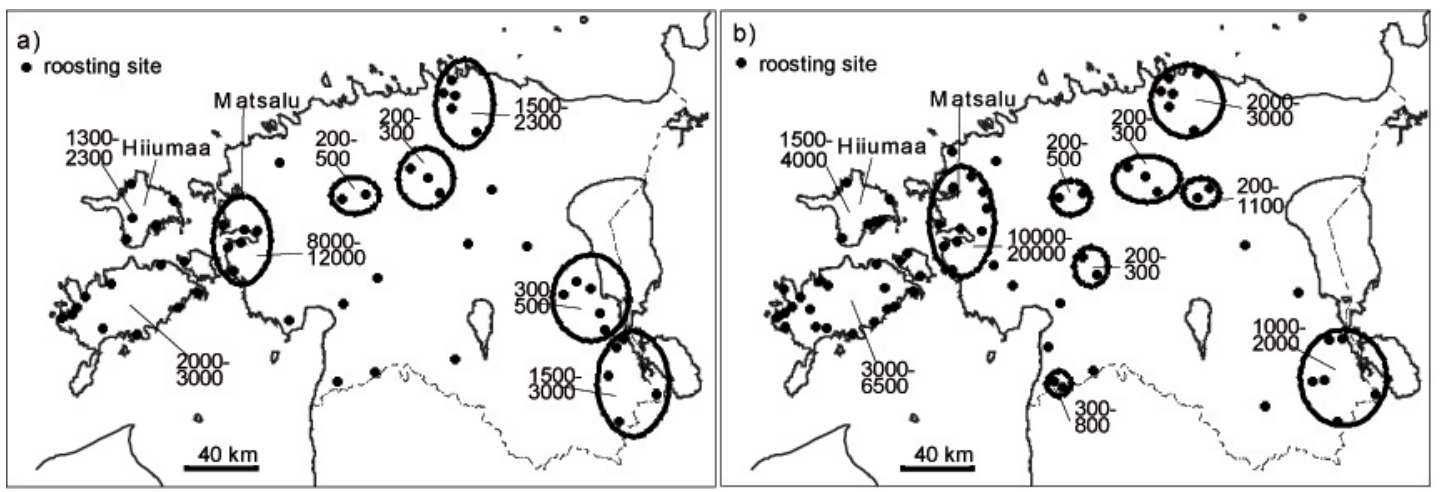

Fig. 4. Distribution of autumn staging Eurasian Cranes in Estonia in the 1980s (a) and 1990s (b).
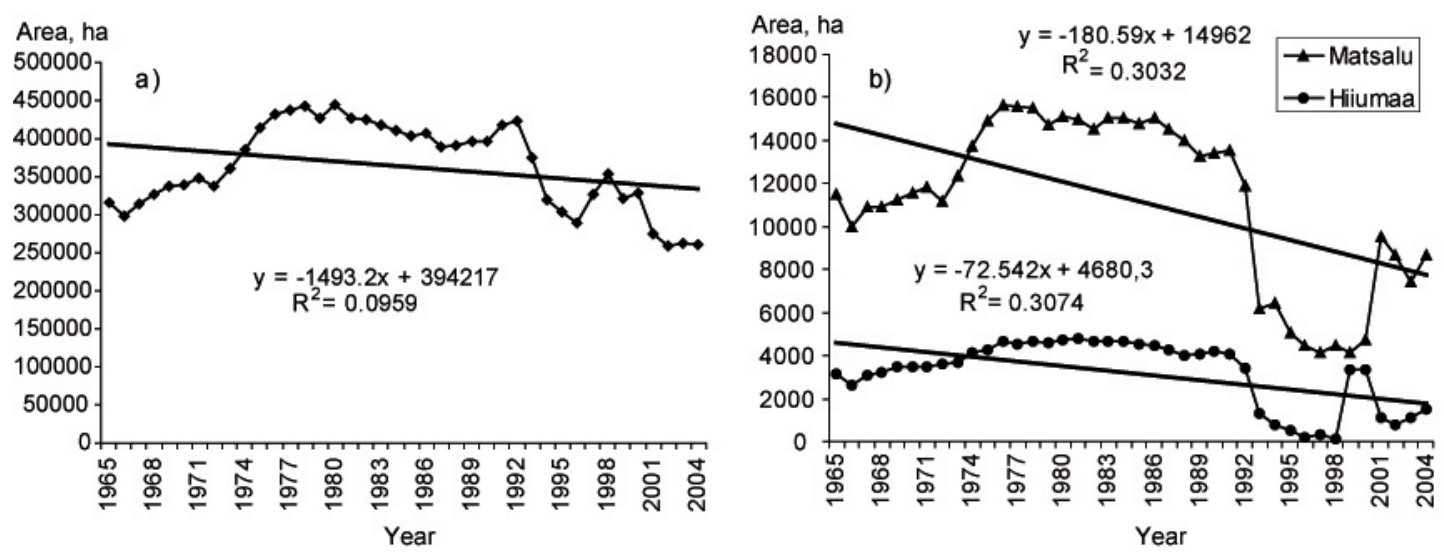

Fig. 5. Total cropping area in the whole of Estonia (a), and in Hiiu and in Lääne Counties separately (b) from $1965-2004$. The trends are not significant ( $M K$ test, $p>0.05, n=40)$. 
Leito et al. The impact of agriculture on migrating cranes

$0.47, p>0.05, n=40$ ) over the whole study period 1965-2004.

The PCA analysis of the total area of cropland in Estonia indicated great changes in the relative share of different field crops in the period 1965-1990: the share of oats and potato had decreased and the share of cultivated grassland had increased (Fig. 6a). The total cropping area of all cereals together, except for summer wheat has decreased since the 1990s. In the
Matsalu area (Läänemaa county) and on Hiiumaa (Hiiumaa county) the changes have been different compared to Estonia as a whole. In Matsalu the relative share of different field crops has been stable during the period 1965-1990, and has changed substantially in the period 1991-1995, when the cropping area of all cereals together decreased. Since 1996 the area of cultivated grassland and summer wheat has decreased (Fig. 6b). On Hiiuma (a)

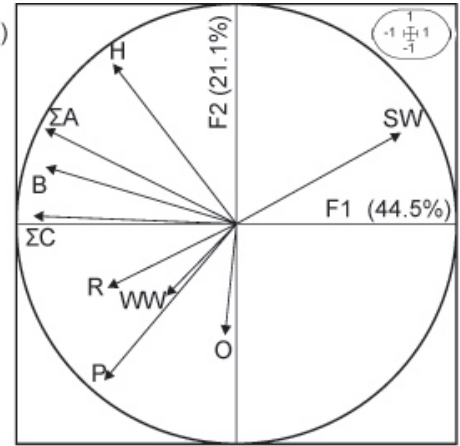

(b)

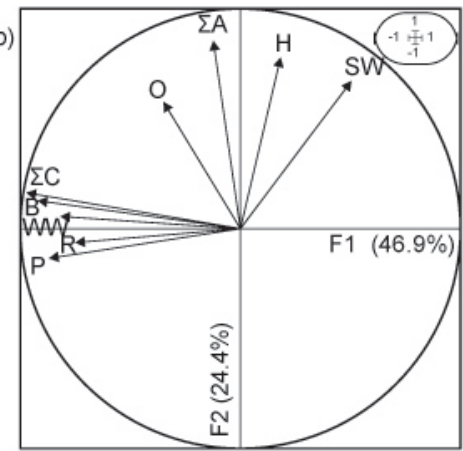

(c)

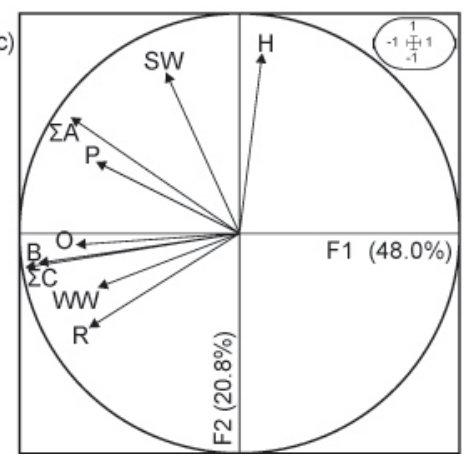

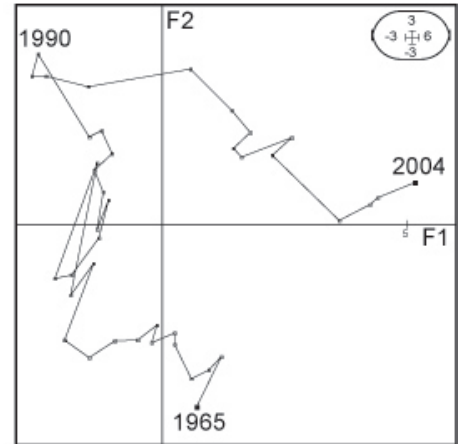
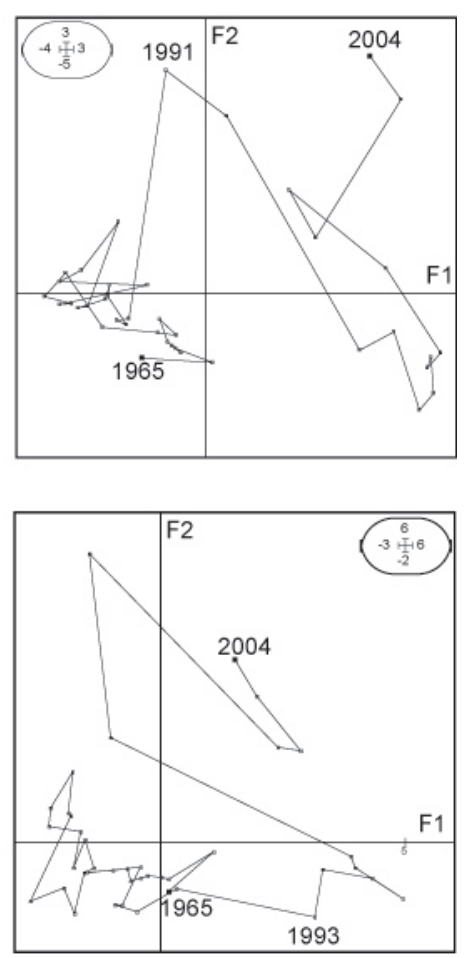

Fig. 6. Results of Principal Component Analysis (PCA) based on the correlation matrix of agricultural land use data. The plots on the left side illustrate the correlation of the agricultural variables (arrows) with the first two axes of $(\mathrm{F} 1 \times \mathrm{F} 2)$ of the PCA. The plots on the right side illustrate the temporal dynamics of consecutive years with respect to the first two principal components: (a) Whole of Estonia, (b) Lääne County (c) Hiiu County. Abbreviations: R winter rye, $\mathrm{WW}$ - winter wheat, SW - summer wheat, B - barley, O - oats, $\Sigma \mathrm{C}$ - total cropping area of cereals, $\mathrm{P}-$ potato, $\mathrm{H}-$ cultivated grassland, $\Sigma \mathrm{A}-$ total area of arable land. 
Vol. 17 (2008): 53-62.

the changes have been similar to Matsalu during the period 1965-1990, but in the period 2001-2004 the structure of cropland on Hiiumaa has been more stable (Fig. 6c).

We found a significant positive correlation between the number of staging cranes and the cropping area of winter rye, winter wheat, summer wheat and all cereals combined, and a negative correlation between crane numbers and the cropping area of potato (Table 1). The correlation was strongest with the cropping area of winter rye $\left(r_{s}=\right.$ $0.58, p<0.05, n=21)$ and winter wheat $\left(r_{s}=0.58\right.$, $p<0.05, n=21$ ) on Hiiumaa, and with the cropping area of all cereals combined in Matsalu $\left(r_{s}=\right.$ $0.56, p<0.05, n=28$ ). No statistically significant correlation between crane numbers and the area of cultivated grasslands was found in either Matsalu or Hiiumaa.

Table 1. Significant Spearman correlation coefficients $\left(r_{s}\right)$ between the cropping area and the number of staging cranes in the Hiiumaa $(n=21$ years $)$ and Matsalu $(n=$ 28 years) areas.

\begin{tabular}{llll}
\hline Locality & Crop & $r_{s}$ & $p$-value \\
\hline Hiiumaa & Winter rye & 0.58 & $<0.05$ \\
Hiiumaa & Winter wheat & 0.58 & $<0.05$ \\
Matsalu & Summer wheat & 0.47 & $<0.05$ \\
Matsalu & Potato & -0.41 & $<0.05$ \\
Matsalu & All cereals together & 0.56 & $<0.05$ \\
\hline
\end{tabular}

\section{Discussion}

We found that the total numbers of Eurasian Cranes staging in Estonia during the autumn migration rose rapidly in the 1960s and 1970s, and stabilized in the 1980s. It is evident, that one reason for the increase in total numbers of autumn staging cranes in Estonia since the 1960s should be the overall growth in crane numbers breeding and passing through (Leito et al. 2006). Unfortunately, we cannot correlate directly the size of the local breeding population and the autumn population because we do not know the proportion of local birds in the autumn counts. On the basis of colour banding and radio tracking we know only that cranes from the local population and from Finland are mixed in Estonia during the autumn migration (Lundin 2005, Leito et al. 2006).

The Eurasian Crane breeding populations and the numbers of autumn staging cranes increased simultaneously up to the 1980s; after that the rise in staging crane numbers stopped, although the breeding population has continued to grow up to the present day (Leito et al. 2003, 2006). This difference is most likely related to agricultural land use changes. We found that staging crane numbers were positively correlated with cropping area of cereals and negatively with the extent of potato fields. It was predictable that the strongest relationship was between crane numbers and the area of winter rye and wheat. This is because, with these crops cranes can feed on newly sown fields and on green crops during one autumn, and on germinated fields and stubbles during the next. In this way the cranes exploit the same fields over a long period during two autumn seasons. Perhaps this is also one of the reasons why the correlation with barley fields was not as strong and was statistically insignificant compared to winter cereals. Breeding cranes are very fond of feeding in germinated barley fields and of picking the grains (Leito et al. 2006), but by the time most migrating cranes arrive in Estonia, the majority of fields have already been harvested, and the birds can only utilize the stubble fields. For that reason barley fields can be used by staging cranes mostly as stubble fields and only during one season. Only local breeding birds and very few early migrants can use germinated barley fields for feeding.

There is a similar but not exactly identical situation with summer wheat in Estonia. Whereas the barley harvest already begins in early August, summer wheat only ripens from late August. Earlyarriving cranes will to a certain extent also feed on the germinated summer wheat fields. Another reason why the correlation between crane abundance and the cropping area of rye and wheat was stronger than with barley may be the greater abundance of other food for cranes, such as insects, amphibians and small mammals on these fields. This aspect of crane food has not been studied in Estonia, but some studies from wintering grounds 


\section{AGRICULTURAL AND FOOD SCIENCE}

\section{Leito et al. The impact of agriculture on migrating cranes}

in Spain demonstrate the importance for cranes of additional food other than the main crop they feed on in their habitat (Reinecke and Krapu, 1986; Díaz et al., 1995; Guzmán et al., 1999; Avilés et al., 2002). Visually, rye and wheat fields seems to be much richer in additional food for cranes, if only because of the higher stand of the germinated crop and stubble compared to barley.

In the summer non-breeding cranes in Estonia locally feed in potato fields (Leito et al. 2006). They pick new potatoes right from the furrow. In the autumn the fields are harvested and only a few potatoes or other food remain for the cranes. The negative correlation between autumn crane abundance and the extent of potato fields can be explained mostly by the conflicting relationship with the area of other crops more important for feeding cranes, i.e. when the area of potato crops in a locality increases, the cropping area of cereals and the potential food source there decrease respectively.

The main driving forces in present day rural landscapes in Estonia are land reforms, political campaigns, land amelioration, concentration and intensification of agricultural production. Most probably, newly cultivated lands, especially large field systems, have been the most important factor for the rise and development of autumn staging crane assemblies in Estonia during the 1950s and 1960s (Leito et al. 2006). During the period from the 1960s to the late 1980s collective farms throughout Estonia were becoming fewer and bigger, and their land use was getting more concentrated to the farm centres and to newly-cultivated fields. By this time large tracts of farm land in the periphery had already been abandoned. These processes were direct results of State policy - to support intensive land use in large collective farms.

After Estonia regained her independence in 1991, the transition from a centralised system to a market economy, land reform, and the privatisation of state farms began (Alanen 1999). This resulted in profound changes in agriculture and related land use. The agricultural reform was carried out during the period from 1992 to1997 - collective farms were dissolved and re-organised mostly into jointstock enterprises or private farms. The changed trade conditions caused vast changes in land-use
- large fields were abandoned and the total area of cereals declined. The cultivation area of agricultural crops decreased and the area of unused arable land increased 20-fold by 1999 (Sepp and Hiiemäe 2003). According to expert estimates, in 1999 there were 330-350 thousand hectares of unused arable land in Estonia. (27-31\% of all arable land). In accordance with the data of the Statistical Office of Estonia (2002), in 2001, 32.6\% of arable land went unused. Some recent changes in the distribution of cranes on migratory routes and in wintering areas are clearly caused by changes in agricultural land use, depending on EU agricultural policy (Alonso et al. 1987, Alonso et al.1994, 2003). More recently, before and after accession to the EU in 2004, rural development programs have been established that encourage the re-cultivation of abandoned agricultural land.

Besides the food sources discussed above, the comprehensive protection of the species and its habitats, and the warming of the climate are probably related to changes (increase) in the distribution and numbers of cranes staging in Estonia in the autumn. The hunting of Eurasian Cranes is currently prohibited in all European countries and illegal hunting is significantly reduced (Meine and Archibald 1996, BirdLife International 2004). In Estonia, the hunting of the Eurasian Crane was prohibited in 1958 and illegal hunting is insignificant (Leito et al. 2006). Also, the establishment of many new protected areas in places where the Eurasian Crane has been breeding and resting has probably contributed to the population growth in Estonia and elsewhere. The proportion of protected areas in Estonia has risen from 4\% in 1970 to $12 \%$ in 1999 and $16 \%$ in 2006 of the total area of the country (Fammler et al. 2000, Leito et al. 2007). Recently, more cranes are wintering in France and Germany, particularly because of climate warming, and their migratory route is shorter compared to earlier times (Cramp and Simmons 1980, Alonso et al. 2003, Lundin 2005). A shorter migration route decreases energy-expenditure and risks during migration, which contribute to a higher survival rate (Berthold 1993, Leito et al. 2003).

In general, we found that migrating crane patterns in Estonia are related to cropping patterns. 
Vol. 17 (2008): 53-62.

And, as the agricultural land use on a county level has changed greatly, depending on agricultural policy, we conclude that it too has had a great impact on migrating cranes. Agri-environmental measures play an important role in decreasing the area of abandoned land and increasing the area of grasslands and cereals. Also direct subsidies to cereal growers have helped enlarge the area of fields that are suitable for the autumn staging of cranes. The resulting abundance of food for staging cranes has led to an increase in crane numbers.

The changes in the pattern of land-use in Hiiumaa and Matsalu have been similar to the general trends in Estonia, except for the last years, when the structure of arable land use in Hiiumaa and Matsalu has been more stable compared to Estonia as a whole.

Acknowledgements. We are very grateful to all those who have taken part in crane censuses in Estonia over the past several years. The Estonian Science Foundation (grants no. 3735 and 6007), the Estonian Ministry of the Environment and the Estonian Environmental Investments Centre provided financial assistance for the performance of Eurasian Crane studies. We are also thankful to Alexander Harding and Ilmar Part for linguistic editing.

\section{References}

Alanen, I. 1999. Agricultural policy and the struggle over destiny of collective farms in Estonia. Sociologia Ruralis 39: 431-458.

Alonso, J.C., Alonso, J.A. \& Bautista, L.M. 1994. Carrying capacity of staging areas and facultative migration extension in Common Cranes. Journal of Applied Ecology 31: 212-222.

Alonso, J.C., Alonso, J.A., Martinez, J.H., Avignon, S. \& Petit, P. 2003. European Cranes shift their wintering area northwards: new evidences from radio-tagged birds. In: Salvi, A. (ed.). Proceedings of 4th European Crane Workshop 2000. Fenentrange-France. p. 201-207.

Alonso, J.C., Veiga, J.O. \& Alonso, J.A. 1987. Possible effects of recent agricultural development on the wintering and migratory patterns of Grus grus in Iberia. In: Archibald G.W. \& Fasquier, R.F. (eds.). Proceedings of III International Crane Workshop. International Crane Foundation, Wisconsin, USA. p. 277-299.

Avilés, J.M., Sánchez, J.M. \& Parejo, D. 2002. Food selection of wintering common cranes (Grus grus) in holm oak (Quercus ilex) dehesas in south-west Spain in rainy season. Journal of Zoology (The Zoological Society of London) 256: 71-79.

Bayliss, J.L., Simonite, V. \& Thompson, S. 2005. The use of probabilistic habitat suitability models for biodiversity action planning. Agriculture, Ecosystems \& Environment 108: 228-250.

Berthold, P. 1993. Bird Migration: A General Survey. Oxford, Ney York, Tokyo: Oxford University Press. 239 p.

BirdLife International 2004. Birds in Europe, trends and conservation status. BirdLife Conservation Series No.12, BirdLife International, Cambridge, UK. 374 p.

Carey, P.D., Manchester, S.J. \& Firbank, L.G. 2005. Performance of two agri-environment schemes in England: a comparison of ecological and multi-disciplinary evaluations. Agriculture, Ecosystems \& Environment 108: $178-188$.

Cramp, S. \& Simmons, K.E.L. (eds.) 1980. The Birds of the Western Palearctic, Vol. II. Oxford: Oxford University press, U.K. 695 p.

Díaz, M., González, E., Muňoz-Pulido, R. \& Naveso, M.A. 1996. Habitat selection patterns of common cranes Grus grus wintering in holm oak Quercus ilex deheses of central Spain: Effects of human management. Biological Conservation 75:119-123.

Fammler, H., Veidemane, K., Ruskule, A., Simanovska, J., Inddriksone, D. Kipper, K. (eds.) 2000. 2nd Baltic State of the environment report based on environmental indicators. Baltic Environment Forum. Riga: Gandrs Ltd. 190 p.

Guzmán, J.M.S., Garacía, A.S. \& Amado, C.C. 1999. Influence of farming activities in the Iberian Peninsula on the winter habitat use of common crane (Grus grus) in areas of its traditional migratory routes. Agriculture, Ecosystems \& Environment 72: 207-214.

Herzog, F. 2005. Agri-environment schemes as landscape experiences. Agriculture, Ecosystems \& Environment 108: 175-177.

Keskpaik, J., Paakspuu, V., Leito, A. Lilleleht, V., Leht, R., Kastepõld, T., Kuresoo, A. \& Rattiste, K. 1986. Autumn concentration of Cranes Grus grus in Estonia. Vår Fågelvärld, Supplementum No. 11. p. 81-84.

Koskinen, P., Koskela, K. \& Rinne, J. 2003. Managing crane damage in Finland: Crane fields and scaring methods. In: Programme and Abstracts of V European Crane Conference, 10-13 April 2003, Sweden. p. 32.

Leito, A., Truu, J., Leivits, A. \& Ojaste, I. 2003. Changes in distribution and numbers of breeding population of the Common Crane Grus grus in Estonia. Ornis Fennica 80: 159-171.

Leito, A., Keskpaik, J., Ojaste, I. \& Truu, J. 2006. The Eurasian Crane in Estonia. Tartu: Eesti Loodusfoto. 184 p.

Leito, T., Kimmel, K. Ader, A. (eds.) 2007. Estonian Nature Reserves. Tartu: Eesti Loodusfoto. 295 p. (In Estonian, with English summary).

Lundin, G. (ed.) 2005. Cranes - where, when and why? Vår Fågelvärd, Supplement 43. 228 p.

Maansoo, S. (ed.) 2001. Estonian Statistical Yearbook 2001. Tallinn: Statistical Office of Estonia. 463 p.

Meine, C.D. \& Archibald, G.W. (eds.) 1996. The cranes: Status, survey and conservation action plan. IUCN, Gland, Switzerland, Cambridge, U.K. 22 p. Available on internet: http://www.npwrc.usgs.gov/resource/birds/ cranes/grusgrus.htm. 


\section{AGRICULTURAL AND FOOD SCIENCE}

Leito et al. The impact of agriculture on migrating cranes

Nowald, G. 2005. Crane`s world today. In: Lundin, G. (ed.). Cranes - where, when and why? Vår Fågelvärd, Supplement 43. p. 17-22.

OECD 2003. Agricultural policies in OECD countries: monitoring and evaluation. Organisation for Economic Cooperation and Development, Paris. 296 p.

Petit, P. \& Couzi, L. 2005. Landes de Gascogne. In: Lundin, G. (ed.). Cranes - where, when and why? Vår Fågelvärd, Supplement 43. p. 141-150.

Prange, H. (ed.) 1989. Der Graue Kranich. Die Neue Brehm-Büherei, Bd. 229. A. Ziemsen Verlag, Wittenberg Lutherstadt. 272 p.

Prange, H. 1999. Der Zug des Kranichs Grus grus in Europe. Die Vogelwelt 120: 301-315.

Prange, H. 2003. Kranichzug, -rast und -schutz in Mitte- leuropa - eine Übersicht. In: Salvi, A. (ed.). Proceedings of 4th European Crane Workshop 2000. FenentrangeFrance. p. 49-70.

Reinecke, K.J. \& Krapu, G.L. 1986. Feeding ecology of sandhill cranes during spring migration in Nebraska. Journal of Wildlife Management 50: 71-79.

Sepp, K. \& Hiiemäe, O. 2003. Land use and land use scenarios. MANTRA East Project. Report No. D2a. 63 p. Available on the internet: http://www.mantraeast.org/ pdf/MANTRA-East_D2a.pdf

Statistical Office of Estonia 2002. Agricultural Census, 2001: General Data. Crop Production. Livestock. Statistical Office of Estonia, Tallinn. 463 pp.

Statistical Office of Estonia 2006. Agriculture. Available on the internet: http://www.stat.ee. 